\title{
ИНФОРМАЦИЯ ВСЕСОЮЗНОГО АГЕНТСТВА ПО АВТОРСКИМ ПРАВАМ (ВААП)
}

В 1988 г. Агентство будет выплачивать гонорар за перепечатку за рубежом статей, опубликованных в нашем журнале в 1984 и 1985 гг.

Прием авторских справок-заявлений на выплату гонорара за статьи и сообщения, опубликованные в журнале в 1984 г., будет прекращен 1 декабря 1988 г. Пропуск сроков направления в ВААП справок-заявлений влечет за собой перечисление невостребованных сумм в доход государства и утрату авторами права на их получение.

Справка-заявление автора оформляется на листе бумаги стандартного формата, напечатанная на пишущей машинке, отдельно на каждое наименование журнала и год его издания.

Указать следующие необходимые для расчета данные:

\section{СПРАВКА-ЗАЯВЛЕНИЕ АВТОРА}

1. Фамилия, имя, отчество

2. Год рождения

(полностью)

3. Наличие детей

(серия, номер свидетельства, когда в кем выдано)

4. Домашний адрес

(адрес прописки)

(обязательно указать почтовы ивдекс)

5. Телефон

(служебный нли домашния)

6. Мон статьи опубликованы в журнале Радиоэлектроника (Изв. высш. учеб. заведений) за 1984 г. (1985 г.)

TOM

№

cтp.

№

стр. ; TOM

No

№

стр. _ _ том

№

cтp.

7. Причитающуюся сумму гонорара прошу начислить в советских рублях, чеках В/O Внешпосылторга (нужное подчеркнуть).

8. Чеки получу лично в Москве, прошу выслать ценным письмом по домашнему адресу (для иногородних авторов, нужное подчеркнуть).

9. Имею (не имеют) льготы по подоходному налогу: удостоверение участника (инвалида) Великой Отечественной войны

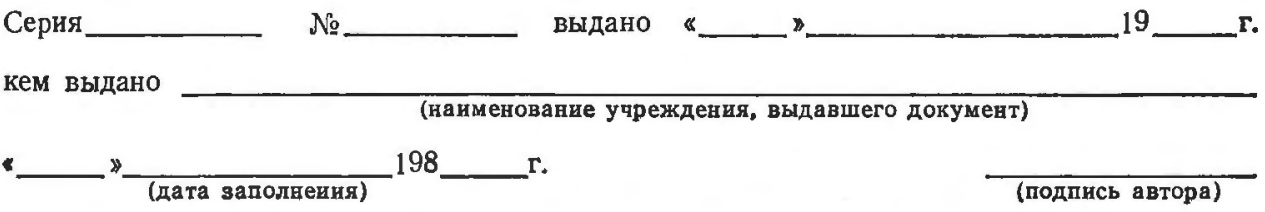

После оформления справка-заявление автора высылается на расчет в Валютное управление ВААП по адресу: 103670 Москва К-104, Б. Бронная, 6 .

Справки-заявления на выплату гонорара принимаются в течение четырех лет с года публикации статьи. Выплата гонорара начинается через 2 года после выхода последнего номера журнала и заканчивается за месяц до истечения срока, установленного для обращения (например, гонорар за перепечатку статей, опубликованных в журналах 1988 г., будет выплачиваться с 1 января 1991 по 1 декабря 1992 г.).

Гонорар в В/O Внешпосылторг перечисляется в течение следующего за подачей справки-заявления квартала, если выплата гонорара уже начата.

Примечание: авторам, проживающим в г. Москве, чеки по почте не высылаются. Для үу получения необходимо обратиться в В/O Внешпосылторг по адресу: Кутузовский проспект, 7/4 (с учетом вышеуказанных сроков отработки документов). Чеки выдаются по предъявлению паспорта. Часы работы: с 8 до 20.00 , кроме субботы и воскресенья.

Справки в ВААП по телефону: 203-59-53.

От редакции: авторам, опубликовавшим свои работы в 1984, 1985 гг. следует заполнить справку-заявление по прилагаемому образщу и отправить ее в валютное управление ВААП, в соответствии с указанными сроками. 